\title{
Hemşirelik Yüksekokulu Birinci Sınıf Öğrencilerinin Duygusal Zekâ Düzeyleri ile Empati Becerileri Arasındaki İlişsi*
}

\author{
The Relationship Between Emotional Intelligence Levels and Empathy Skills of \\ Nursing College's First Grade Students
}

\author{
Demet DUMAN**, Rengin ACAROĞLU***
}

İletişim/Correspondence: Rengin ACAROĞLU Adres/Adress: İ.Ü. Florence Nightingale Hemşirelik Fakültesi, Abide-i Hürriyet Cad. 34381 Şişli/İstanbul Tel: 02124400000 / 27004 Fax: 02122244990 E-mail: rencar@istanbul.edu.tr

$\ddot{O} Z$

Amaç: Araştırma hemşirelik yüksekokulu birinci sınıf öğrencilerinin duygusal zekâ düzeyleri ve empatik becerileri arasindaki ilişkiyi incelemek amacıyla gerçekleştirildi.

Yöntem: Tanımlayıcı ve ilişki arayıcı olarak planlanan araştırmanın örneklemini, bir hemşirelik yüksekokulunda 20082009 eğitim-öğretim yılı bahar yarıyılında öğrenim görmekte olan ve araştırmaya gönüllü olarak katılmayı kabul eden 125 ögrenci oluşturdu. Veriler, ögrencilerin sosyodemografik özelliklerini içeren anket formu, Duygusal Zekâ Değerlendirme Ölçeği ve Empatik Beceri Ölçeği ile toplandl. Elde edilen veriler SPSS 15.0 (Statistical PackagefortheSocialSciences) paket programı ile analiz edildi.

Bulgular: Öğrencilerin yaş ortalaması 20.04 1.24, \%72.8’inin kız ögrencilerden oluştuğu, saptandı. Öğrencilerin duygusal zekâ toplam puan ortalaması 116.0 \pm 19.7 , empatik beceri puan ortalamasi $124.7 \pm 14.3$ idi. Duygusal zekâ puan ortalaması ile empatik beceri puan ortalaması arasında istatistiksel olarak anlaml, pozitif yönde ve orta düzeyde anlamlı bir ilişki belirlendi $(r=0.664, p<0.01)$.

Sonuç: Araştırma kapsamına alınan hemşirelik yüksekokulu birinci sınıf ögrencilerinin duygusal zekâ ve empatik beceri düzeylerinin düşük olduğu, duygusal zekâ düzeyleri ile empati becerilerinin birbirini pozitif yönde etkilediği saptandl. Anahtar Kelimeler: Öğrenci hemşire, duygusal zekâ, empatik beceri.

\begin{abstract}
Aim: The aim of the research was to examine the relationship between emotional intelligence levels and empathy skills of nursing college's first grade students.

Method: A descriptive and correlational study was conducted with 125 students who agreed to participate on a voluntary basis, in a nursing college in 2008-2009 the spring semester of academic year. Data were collected with a questionnaire including socio-demographic characteristics of the students, and Emotional Intelligence Evaluation Scale and Empathy Skill Scale. In the analysis of data, frequency, percentage, mean, standard deviation and correlation analysis were performed using SPSS Package Programme.

Results: The average age of students was $20.04 \pm 1.24,72.8 \%$ of students is composed of the girls. The mean total score of students was 116.0 \pm 19.7 for emotional intelligence, and for empathy skills was $124.7 \pm 14.3$. Emotional intelligence and empathy skills of the average total score between the mean scores was statistically signicifanta moderate positive correlation was observed $(r=0.664, p<0.01)$.

Conclusion: The level of emotional intelligence and empathy skills of the nursing college's first grade students including in the research was low, and between their emotional intelligence levels and empathy skills, a positive correlation was seen. Key Words: Nursing students, emotional intelligence, empathy skill.
\end{abstract}

*İstanbul Üniversitesi Sağllk Bilimleri Enstitüsü Yüksek Lisans Tezi (2010), ** Uzm. Hemşire İstanbul Üniversitesi Sağlık Bilimleri Enstitüsü Yüksek Lisans Mezunu, ***Doç.Dr. İstanbul Üniversitesi Florence Nightingale Hemşirelik Fakültesi

Yazının gönderilme tarihi: 15.05.2013

Yazının basım için kabul tarihi: 10.01.2014 


\section{GİRIŞ}

Duygusal zekâ ve empati insan sağlığı ile ilgili alanlarda çalışanların başarılı ve etkin hizmet sunmalarında rol oynayan önemli iletişim becerileridir. Yapılan çalışmalar bu becerilerin, bireyler arasında olumlu etkileşimi güçlendirmesinin yanı sıra hizmet sunanların kişisel ve mesleki yaşamlarından doyum sağlamalarında da önemli etkisi olduğunu göstermektedir (Ioannidou ve Konstantikaki 2008; McQueen 2003; Stein ve Book 2003; Y1lmaz 2007; Zeidner, Matthews ve Roberts 2004).

Duygusal zekâ, 1995 yılında psikolog Daniel Goleman tarafından yayınlanan bir kitap ile geniş kitlelere tanıtılan bir kavramdır. Bireyin, öncelikle kendi duygularını anlamasını ve yönetebilmesini sağlayan, bunun yanında başkalarının duygularını anlayabilme, empati kurabilme, motivasyonunu artırma ve özgüven duygusunu geliştirmesine olanak veren bir zekâ bileşenidir (Akkoç 2007; Goleman 2007). Empati ise yaygın olarak kabul gören tanımı ile bir kişinin kendisini karşısındakinin yerine koyarak, olaylara onun bakış açısı ile bakması, o kişinin duygu ve düşüncelerini doğru olarak anlaması, hissetmesi ve durumu ona iletmesi sürecidir (Akerjordet ve Severinsson 2007; Mercer ve Reynolds 2002). Duygusal zekâ ve empati, ahlaki, bilişsel, duygusal ve davranışsal bileşenleri olan karmaşık, çok boyutlu, birbiri ile etkileşen, öğretilebilen ve öğrenilebilen güçlü iletişim araçlarıdır (Akkoç 2007; Ioannidou ve Konstantikaki 2008; Tutuk ve Doğan 2002; Ward, Cody, Schaal ve Hojat 2012).

Hemşirelik insan-insana ilişkinin en yoğun yaşand1ğ sağlık disiplinlerinden biridir. Hemşire temel sorumluluğu olan yardım etme eyleminde gerçekleştirdiği bakım işlevlerini, sağl1klı / hasta bireylerle kurduğu ilişski yoluyla yerine getirir ve bu profesyonel ilişki bakımın odak noktasını oluşturur. $\mathrm{Bu}$ anlamda, hemşirelerin duygusal zekâ ve empati becerilerinin gelişmiş olması beklenir (Ioannidou ve Konstantikaki 2008; Karakaş ve Küçükoğlu 2011; Karakaya 2001). Nitekim, Peplau ve Orlando gibi hemşire kuramcilar, sağlıkl1/hasta bireylerin gereksinimlerini her zaman açıkça ortaya koyamadıklarını, hemşirenin onların gereksinimlerinin neler olduğunu anlayabilmek için etkin kişilerarası ilişki becerisine sahip olması gerektiğini vurgularlar (Freshwater ve Stickley 2003). Hemşirenin, bireyi önemli, değerli, benzersiz bir insan olarak kabul etmesi, sayg1 duyması ve empatik yaklaşımı bireyin hemşireye güvenmesini sağlayarak aralarındaki profesyonel ilişkiyi güçlendirecek ve bakımın kalitesini olumlu yönde etkileyecektir. Hemşirenin empati becerisinin gelişmemiş ya da düşük düzeyde olması ise bireyin anlaşılamaması ya da anlaşıldığını hissedememesine dolayısı ile gereksinimlerinin yeterince karşılanamamasına yol açarak bakımının amacına ulaşmasını ve başarısını engelleyecektedir (Mercer ve Reynolds 2002; Mete ve Gerçek 2005; Nunes, Williams, Sa ve Stevenson 2011; Tutuk 2002).Yapılan araştırmalar, bakımda hasta ile empati kuran hemşirelerin, kuramayanlara göre hastasına daha fazla yardımcı olduğunu göstermektedir (Özcan, Oflaz ve Çiçek 2008).

Hemşirelerde empati becerisinin yanı sıra duygularının farkında olma ve duygularını kontrol etme, amaca ulaştıracak motivasyonu harekete geçirme, diğer kişilerin duygu ve düşüncelerini dikkate alarak iletişimi sürdürme gibi bileşenleri içeren duygusal zekâ becerisinin gelişmiş olması ile yakından ilişkilidir. $\mathrm{Bu}$ beceri, hemşirenin karşılaştı̆̆ stresli durumların üstesinden gelmesini, sorunları zorlanmadan çözümlemesini ve yeterlilik duygusu ile kendini başarılı hissetmesini sağlar (Ioannidou ve Konstantikaki 2008). Nitekim literatürde, duygusal zekâ becerisi yüksek hemşirelerin buna paralel olarak problem çözme becerilerinin geliştiği vurgulanmaktadır (Augusto Landa, Lopez-Zafra, Berrios Martos ve Aguilar-Luzon Mdel 2008; Karabulutlu, Yılmaz ve Yurttaş 2011; Yurttaş 2011).

Hasta hemşire arasında, bakım ilişkisinin kurulması ve sürdürülmesine yönelik bilginin gelişimi için değerli bir nitelik olmasının yanı sıra hemşirelik sanatının da önemli bir boyutunu oluşturan ve birbirini tamamlayan bu beceriler, meslek adaylarına temel eği- 
timleri sırasında kazandırılmalı ve uygulamalar ile geliştirilmelidir. Konuya ilişkin çalışmalarda, hemşirelik öğrencilerinde hem duygusal zekâ (Avşar ve Kaş1kç1 2010; Kuzu ve Eker 2010; Sevindik, Uncu ve Dağ 2012; Yılmaz ve Özkan 2011) hem de empati becerilerinin (Akıncı ve Akgün 2011; Arifoğlu ve Razı 2011; Nazik ve Arslan 2011; Nunes ve ark. 2011) genellikle düşük ya da orta düzeyde olduğu belirtilmekte ve eğitim müfredatlarında bu durumun dikkate alınmasının gerekliliği üzerinde durulmaktadır. Öğrencilerin bakım verirken göstereceği davranışların niteliğini ve kişilerarası ilişki becerisinin etkinliğini belirleyecek duygusal zekâ ve empati becerilerinin gelişerek davranışa dönüşmesi, başarılı meslek üyeleri olmalarına katkı sağlayacaktır (Ioannidou ve Konstantikaki 2008). Bu bağlamda, hemşirelik öğrencilerinin öğrenimlerinin başlangıcında, duygusal zekâ ve empati becerilerinin birlikte değerlendirilerek hazır oluşluklarının belirlenmesi ve hemşireliğin hem bilişsel hem de duyuşsal alanına ilişkin bu becerileri destekleyici ve geliştirici nitelikte eğitim programlarının yapılandırılması gerekir. Programların içeriğinin belirlenmesinde ise öğrencilerin mevcut durumlarının dikkate alınması yol gösterici olacaktır.

Bu doğrultuda çalışma, hemşirelik yüksekokulu birinci sınıf öğrencilerinin duygusal zekâ ve empatik becerileri ile bu becerileri arasındaki ilişkiyi incelemek amacı ile planlandı ve aşağıdaki sorulara yanıt arand1;

- Hemşirelik yüksekokulu birinci sınıf öğrencilerinin duygusal zekâ düzeyleri nedir?

- Hemşirelik yüksekokulu birinci sınıf öğrencilerinin empatik beceri düzeyleri nedir?

- Öğrencilerin duygusal zekâ ve empati becerileri arasında ilişki var mıdır?

\section{YÖNTEM}

\section{Araştırmanın Evren ve Örneklemi}

Tanımlayıcı ve ilişki arayıcı türdeki araştırmanın evrenini İstanbul'da bir devlet üniversitesinin Hemşirelik Yüksekokulunda, 2008-2009 eğitim-öğretim y1l bahar döneminde öğrenimlerini sürdüren birinci s1- nıf öğrencilerinin tamamı (150 öğrenci) oluşturdu. Örneklem ise, verilerin toplandığı gün okulda bulunan ve araştırmaya gönüllü olarak katılmayı kabul eden 125 öğrenciden oluştu.

\section{Veri Toplama Araçları}

Veriler, literatür doğrultusunda geliştirilen ve öğrencilerin demografik özelliklerini içeren Görüşme Formu, Duygusal Zekâ Değerlendirme Ölçeği ve Empatik Beceri Ölçeği kullanılarak toplandı.

\section{Duygusal Zekâ Değerlendirme Ölçeği}

Duygusal Zekâ Değerlendirme Ölçeği (DZDÖ) duygusal zekâ düzeyini değerlendirmek amacı ile 1999 yılında NickHall tarafından geliştirilmiştir. Ölçeğin Türk toplumuna uyarlanması Ergin (2000) tarafından yapılmış ve ülkemizdeki araştırmalarda kullanılmıştır (Avşar ve Kaşıkçı 2010; Kaya ve Keçeci 2004; Kuzu ve Eker 2010; Ünsar ve ark. 2008; Y1lmaz 2007). Toplam 30 maddeden oluşan ölçek, "Duyguların Farkında Olma" (madde 1, 2, 4, 17, 19, 25), "Duygularını Yönetme" (madde 3, 7, 8, 10, 18, 30), "Kendini Motive Etme" (madde 5, 6, 13, 14, 16, 22), "Empati" (madde 9, 11, 20, 21, 23, 28) ve "Sosyal Beceriler" (madde 12, 15, 24, 26, 27, 29) olmak üzere beş alt boyut içermektedir. Likert tipinde hazırlanan ölçekte madde puanlamas1 "tamamen katılmıyorum" (1 puan), "k1smen katılmıyorum" (2 puan), "çok az katılmıyorum" (3 puan), "çok az katılıyorum” (4 puan), "kısmen kat1lyorum" (5 puan), "tamamen katıliyorum" (6 puan) şeklinde yapılır. Değerlendirmede tersine çevrilen ifade bulunmamaktadır. DZDÖ toplamından alınan 155 ve üzeri puan yüksek (oldukça güçlü), 130-150 aras1 puan normal (biraz geliştirilmeye ihtiyaç var), 129 ve altı puan ise düşük (kesinlikle geliştirilmeye ihtiyaç var) duygusal zekâ düzeyi olarak değerlendirilmektedir (Ergin 2000).

\section{Empatik Beceri Ölçeği}

Empatik Beceri Ölçeği (EBÖ), Dökmen tarafından bireyin empati kurma becerisini ölçmek amacı ile Aşamalı Empati Sınıflaması'na dayandırılarak 1988 yılın- 
da geliştirilmiştir. EBÖ A ve B formlarından oluşmaktadır. A formunda ölçeğin değerlendirmesinin nasıl yapılacağı açıklanır. B formunda ise günlük yaşam ile ilgili kısa paragraflarla ifade edilmiş altı ayrı psikolojik sorun ve bu sorunların her biri için birer cümlelik 12 farklı tepki bulunmaktadır. Tepkilerden bir tanesi anlatılan psikolojik sorunla ilgisizdir ve soruları yanıtlayan kişilerin dikkatini kontrol etmek için konulmuştur. Ölçeğin uygulandığı kişiler, psikolojik sorunla ilgisiz olan tepki cümlelerinden toplam 5 tanesini işaretlediğinde, tepki cümlelerini dikkatli okumadıkları gerekçesiyle değerlendirme dişı bırakılır. Uygulayıc1dan, ölçekteki kısa paragraflarla ifade edilen 6 psikolojik sorunun her biri için dört empatik tepki cümlesini seçmesi istenir ve toplam olarak 24 tepki cümlesi elde edilir. Seçilen her bir empatik cümleye, A formunda belirtilen standart puanlama doğrultusunda puan verilir. EBÖ’den alınabilecek en yüksek puan 219, en düşük puan 41'dir. Yüksek puan yüksek empati becerisini gösterirken, düşük puan düşük empati becerisini gösterir (Dökmen 1988).

\section{Araştırmanın Etik Yönü}

Araştırma verileri, İstanbul Üniversitesi Cerrahpaşa Tıp Fakültesi Etik Kurulundan etik onay, araştırmanın yürütüleceği kurumdan yazılı izin alındıktan sonra toplandı. Öğrencilere çalışmanın amacı, kendilerinden ne beklenildiği ve yasal hakları konusunda bilgilendirme yapılarak sözel izin alındı. Elde edilen bilgilerin gizli tutulacağı güvencesi verildi.

\section{Verileri Analizi}

Araştırma verilerinin istatistiksel analizi, bilgisayar ortaminda SPSS 15.0 (Statistical Packageforthe Social Sciences) paket programında say1, yüzdelik, ortalama, standart sapma ve korelasyon analizi kullanılarak yapildi.

\section{BULGULAR}

Araştırmaya katılan öğrencilerin yaş ortalaması 20.04 \pm 1.24 yıl, \%72.8'i kız öğrenci, \%33.9'u düz lise mezunu idi (Tablo 1).
Tablo 1. Öğrencilerin Demografik Özelliklerine İlişkin Bulgular $(\mathrm{N}=125)$

\begin{tabular}{|c|c|c|c|}
\hline Özellikler & & Sayı & Yüzde \\
\hline Yaş & & \multicolumn{2}{|c|}{$20,04 \pm 1,24$} \\
\hline Cinsiyet & $\begin{array}{l}\text { K1z } \\
\text { Erkek }\end{array}$ & $\begin{array}{l}91 \\
34\end{array}$ & $\begin{array}{l}72.8 \\
27.2\end{array}$ \\
\hline $\begin{array}{l}\text { Mezun } \\
\text { Olunan } \\
\text { Okul Türü }\end{array}$ & $\begin{array}{l}\text { Fen-Anadolu Lisesi } \\
\text { Yabancı Dil Ağırlıklı Lise } \\
\text { Sağlık Meslek Lisesi } \\
\text { Düz Lise } \\
\text { Diğer Liseler } \\
\text { Ön Lisans } \\
\text { Toplam }\end{array}$ & $\begin{array}{c}26 \\
28 \\
14 \\
42 \\
11 \\
3 \\
124\end{array}$ & $\begin{array}{c}21.0 \\
22.6 \\
11.3 \\
33.9 \\
8.9 \\
2.4 \\
100.0\end{array}$ \\
\hline
\end{tabular}

Öğrencilerin Duygusal Zekâ Değerlendirme Ölçeği toplam puan ortalaması $116.0 \pm 19.7$ bulundu. Öğrencilerin DZDÖ alt boyutlarına ilișkin puan ortalamalarının $22.8 \pm 4.6$ ile $23.8 \pm 4.7$ arasında birbirine oldukça yakın değerlerde olduğu görüldü. Öğrencilerin Empatik Beceri Ölçeğinden aldıkları toplam puan ortalamas1 ise $124.7 \pm 14.3$ idi (Tablo 2).

Tablo 2. Öğrencilerin DZDÖ ve EBÖ Puan Ortalamaları (N=125)

\begin{tabular}{|l|l|l|}
\hline & \multicolumn{1}{|c|}{$\mathbf{X} \pm \overline{S S}$} & \multicolumn{1}{c|}{ Min- Max } \\
\hline Duygusal Zekâ & $116.0 \pm 19.7$ & $45-165$ \\
\hline Duyguların Farkında Olma & $23.8 \pm 4.7$ & $11-36$ \\
\hline Duyguları Yönetme & $22.8 \pm 4.6$ & $8-33$ \\
\hline Kendini Motive Etme & $23.0 \pm 4.6$ & $8-34$ \\
\hline EmpatikOlma & $23.2 \pm 4.6$ & $10-35$ \\
\hline Sosyal Beceriler & $23.2 \pm 5.1$ & $7-34$ \\
\hline Empatik Beceri & $124.7 \pm 14.3$ & $87-179$ \\
\hline
\end{tabular}

Öğrencilerin Duygusal Zekâ Değerlendirme Ölçeği ve Empatik Beceri Ölçeği toplam puan ortalamaları arasinda orta düzeyde pozitif yönde ve istatistiksel olarak anlamlı bir ilişki olduğu belirlendi $(\mathrm{r}=0.664, \mathrm{p}<0.01)$. Öğrencilerin duygusal zekâ düzeyi yükseldikçe empati becerilerinin de arttığı saptandı (Tablo 3).

Duygusal Zekâ Değerlendirme Ölçeği alt boyut puan ortalamalarının Empatik Beceri Ölçeği puan ortalamaları ile ilişkisi incelendiğinde; Empatik Beceri Ölçeği puan ortalaması ile "Empati" alt boyutu puan ortalaması arasında yüksek $(r=0,774, p<0,01)$; "Duyguların Farkında Olma $(r=0.534, p<0.01)$ " ve "Kendini Mo- 
Tablo 3. Öğrencilerin DZDÖ ve EBÖ Puan Ortalamaları Arasındaki İlişki

\begin{tabular}{|l|c|c|}
\hline & \multicolumn{2}{|c|}{$\begin{array}{c}\text { Empatik } \\
\text { Beceri Ölçeği }\end{array}$} \\
\hline & R & \multicolumn{1}{c|}{ p } \\
\hline Duygusal ZekâDeğerlendirme Ölçeği & 0.664 & $<0.01$ \\
\hline DuygularınınFarkında Olma & 0.534 & $<0.01$ \\
\hline DuygularınıKontrol Etme & 0.484 & $<0.01$ \\
\hline Kendini Motive Etme & 0.508 & $<0.01$ \\
\hline Empati & 0.774 & $<0.01$ \\
\hline Sosyal Beceriler & 0.488 & $<0.01$ \\
\hline
\end{tabular}

tive Etme $(\mathrm{r}=0,508, \mathrm{p}<0,01)$ " alt boyutları puan ortalamaları arasında orta;"Duyguları Yönetme $(\mathrm{r}=0.484$, $\mathrm{p}<0.01)$ " ve "Sosyal Beceriler $(\mathrm{r}=0,488, \mathrm{p}<0,01)$ " alt boyutları puan ortalamaları arasında ise zayıf, pozitif yönde anlamlı bir ilişki olduğu belirlendi (Tablo 3).

\section{TARTIŞMA}

Çalışma, hemşirelik öğrencilerinin, öğrenimlerine başladıklarında, birbiri ile pozitif etkileşim içinde olan duygusal zekâ ve empatik beceri düzeylerinin değerlendirilmesinin, gereksinimleri doğrultusunda destekleyici ve geliştirici nitelikte eğitim içeriğinin yapılandırılmasına rehberlik edeceğini vurgulayan literatüre dayanılarak (Akerjordet ve Severinsson 2007; Cevahir ve ark. 2007; Freshwater ve Stickley 2003; Ioannidou ve Konstantikaki 2008; Stein ve Book 2003) tasarlandı ve gerçekleştirildi.

Örneklem grubunu oluşturan öğrencilerin yaş, cinsiyet, mezun oldukları ortaöğretim türü gibi demografik özellikleri (Tablo 1), ülkemizde, hemşirelik yüksekokulu birinci sınıfta öğrenimlerini sürdüren öğrenciler ile yürütülen çalışmalardan elde edilen bulgular ile benzerlik gösterdi. (Arifoğlu ve Razı 2011; Avşar ve Kaşıçç 2010; Karabulutlu ve ark. 2011; Nazik ve Arslan 2011; Ünsar ve ark. 2008).

Çalışma kapsamına alınan öğrencilerin116,0 $\pm 19,7$ toplam puan ortalaması ile duygusal zekâ düzeylerinin düşük olduğu belirlendi (Tablo 2). Öğrencilerin duygusal zekâ düzeylerinin mutlaka desteklenerek geliştirilmesi gerekliliğini gösteren bu bulgu, birinci sınıf hemşirelik öğrencilerinde duygusal zekâ düzeyini düşük (Kuzu ve Eker 2010; Sevindik ve ark. 2012) ve orta düzeyde (Avşar ve Kaşıkçı 2010; Yı1maz ve Özkan 2011) bulan çalışmaların sonuçları ile paraleldi.

Buna karşın hemşirelik öğrencilerinin duygusal zekâ düzeyinin normal sınırlar içinde olduğunu gösteren çalışma bulgularına da rastlandı (Kaya ve Keçeci 2004; Onay ve Uğur 2011; Ünsar ve ark. 2008). Duygusal zekâ, insan doğasının varlığını ön plana çıkaran hümanist varoluşçu bakış açısından bakım kalitesini artıran önemli bir olgudur. Duygusal zekâ, daha olumlu tutumlara, daha fazla uyuma, gelişmiş ilişsilere ve değerlere karşı oryantasyonu artırmanın bir yolu olarak kabul edilmekte ve bu emosyonel beceriler için öğrencilerin bir alt yapıya sahip olmasının önemi vurgulanmaktadır (Akerjordet ve Severinsson 2007). Bu bulgu, birinci sınıf öğrencilerinde düşük de olsa var olan bu alt yapının destekleyici bir müfredat içeriği ile zenginleştirilebileceğini düşündürdü. Ancak üst sınıflardaki öğrencileri ve mezunları kapsayan çalışmaların sonuçları, hem öğrencilerde (Karabulutlu ve ark. 2011; Sevindik ve ark. 2012) hem de hemşirelerde (Karakaş ve Küçükoğlu 2011; Onay ve Uğur 2011; Uygun 2006) duygusal zekâ düzeyinin beklenildiği gibi gelişmediği göstermekte ve mesleki eğitim sırasında duygusal zekâ gelişimine yeterince yer verilmediğine dikkat çekmektedir (Freshwater ve Stickley 2003; Kaya ve Keçeci 2004; Özcan ve ark. 2008).

Çalışmada duygusal zekâ değerlendirme ölçeğinin alt boyutlarına ilişkin puan ortalamalarının da düşük düzeyde olduğu, en düşük puan ortalamasının ise "Duyguları Yönetme" alt boyutundan alındığı saptandı (Tablo 2). Duygusal zekâ gelişimindeki aksaklıklar hem insanlararası ilişkilerde hem de mesleki başarıda çok önemli bir role sahiptir. Her insanın, duygusal zekânın bu beş farklı alanındaki yetiler açısından farklılıklar gösterebileceğinin kabul edilebilir olduğu, ancak sağlık bakımında sorumluluk üstlenen disiplin üyelerinde, özellikle hemşire ve hekimlerde, hastaları 
ile kuracakları terapötik ilişki için bu becerilerin vazgeçilmez bir nitelik olduğu belirtilmektedir (McQueen 2003; Onay ve Uğur 2011). Öğrenciler ve hemşirelerde, aynı ölçekten yararlanarak, duyusal zekâyı değerlendiren çalışmalar incelendiğinde, en düşük puan ortalamalarının da bu alt boyutta yer aldığı gözlenmektedir (Karakaş ve Küçükoğlu 2011; Kuzu ve Eker 2010; Ünsar ve ark. 2008). Oysa, duyguların farkında olma ve duygularını kontrol etme becerileri duygusal zekânın en temel bileşenleri olarak ele alınmaktadır. Kişi, ancak kendi duygularını ve hislerini tam olarak algılayabildiğinde ve bunları yönetmeyi öğrendiğinde başkaları ile ilişkisinde başarıya ulaşabilecektir (Akerjordet ve Severinsson 2007; Akkoç 2007). Duygusal zekâ hem duyuşsal hem de bilişsel gelişim süreçlerine odaklanan bir öğrenme modeli ile gerçekçi ve uygun şekilde hemşirelik eğitimine entegre edilebilir (Ioannidou ve Konstantikaki 2008).

Öğrencilerin Empatik Beceri Ölçeği puan ortalamas1

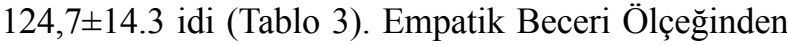
alınabilecek en yüksek puanın 219 olduğu göz önüne alındığında, öğrencilerin empati beceri puan ortalamasının oldukça düşük olduğu belirlendi. Birinci s1nıf hemşirelik öğrencilerinde empati becerilerini inceleyen çalışmalarda, her ne kadar öğrencilerin empatik beceri puan ortalamaları değişse de, genelde bu becerilerinin yüksek olmadığı görülmektedir (Akıncı ve Akgün 2011; Arifoğlu ve Akın 2011; Cevahir ve ark. 2007; Nazik ve Arslan 2011). Nunes ve ark. (2011) tarafından yapılan bir çalışmada da birinci sınıf hemşirelik öğrencilerinin, diğer sağlık bilimlerindeki öğrencilere göre daha yüksek puan ortalamasına sahip olmakla birlikte, empati becerilerinin geliştirilmeye gereksinimi olduğu saptanmıştır. Yapılan çalışmalar, hemşirelerde de empati becerisinin yüksek olmadığını göstermektedir (Karakaş ve Küçükoğlu 2011; Özcan 2012; Uygun 2006). Hemşirelerin ve öğrencilerin karşısındaki birey ile empati kurabilme becerisine sahip olması hasta bireyi doğru anlama dolayısı ile gereksinimlerini doğru belirleme ve karşılanmasına yardım etmede önemli bir ölçüt olarak ele alınmaktadır (Mercer ve Reynolds 2002; Nunes ve ark. 2011; Ward ve ark. 2012).
Hemşirelerin güçlü bir empati becerisine sahip olabilmesi, öncelikle kendini tanıma ve anlama, duygularını dikkate alma ve kendine hakim olabilme, özetle duygusal zekâsını geliştirmesine bağlıdır (Akerjordet ve Severinsson 2007). Diğer taraftan empati ise duygusal zekânın beş bileşeninden birisidir. Bu becerilerin gelişiminin birbiri ile yakın ilişki içinde olduklar1 göz ardı edilmemelidir (Ioannidou ve Konstantikaki 2008). Nitekim çalışmada öğrencilerin hem duygusal zekâ hem de empati becerileri arasında orta düzeyli pozitif yönde anlamlı bir ilişki olduğu saptanmıştır. Kişilerarası ilişki üzerine temellenen bakım eylemlerinin amacına ulaşması, sağlıkl1/hasta bireyin bakıma gereksinim duyduğu sorun ya da davranışının altında yatan asıl anlamı ifade edebilmesine olanak sağlayacak güven ilişkisinin kurulması ve sürdürülmesi ile olasıdır (McQueen 2003). Bakım sürecinde hemşireler bir yandan sözel ve sözel olmayan iletiler yoluyla bireyin duygu ve düşüncelerini anlamaya çalışırken diğer yandan kendi duygularını kontrol ederek hasta bireyle kurulan dual bakım ilişkisini dinamik tutabilmelidir. Bu anlamda, öğrencilerin duygusal zekâ ve empati becerilerinin mesleki eğitim sürecinde geliştirilerek mesleğe hazırlanması gerekir. Ancak bunun için ön koşul öğrencilerin hemşireliğin ve hemşire olabilmenin gereklilikleri konusunda bilinçli ve hazır gelerek eğitime başlamalarının önemi de göz ardı edilmemelidir.

\section{Çalışmanın Sınırlılıkları}

Bu çalışma yalnızca bir hemşirelik yüksekokulu birinci sınıf öğrencilerini ile yapıldı̆̆g için genelleme yapılamaz. Ancak konu ile ilgili yapılacak çalışmalar için veri ve bir bakış açısı sağlar.

\section{SONUÇ VE ÖNERILLER}

Çalışmadan elde edilen bulgular, hemşirelik yüksekokulu birinci sınıf öğrencilerinin duygusal zekâ ve empati becerilerinin düşük olduğunu, bu beceriler arasında orta düzeyli pozitif yönde anlamlı bir ilişki bulunduğunu gösterdi. Hemşirelik bakımı, sağlıklı/hasta bireyler için terapötik olarak bir varoluştur. Bu varoluş- 
ta, kuramsal bilgi ve uygulama becerilerinin yanı sıra alturistik bir yaklaşımla bireyi anlama ve güvenli bir ilişkiyi oluşturma ön koşuldur. Bu ilişkinin sürdürülmesi ise hemşirenin kendisini ve duygularının farkında olması ve bu duyguları kontrol altında tutabilmesi ile olasıdır. Bu anlamda, duyguların ve ilişkilerin yönetilebilmesinde uyumlu bir birlikteliği olan duygusal zekâ ve empati, hemşirelik öğrencilerine kazandırılması gereken temel becerilerdir. Bu doğrultuda, mesleki eğitimlerinin başlangıcında, öğrencilerin duygusal zekâ ve empati becerilerine ilişkin yeterlik düzeylerinin değerlendirilmesi ve elde edilen sonuçlardan, ilgili derslerin müfredat içeriğini oluşturma, öğretim yöntemlerini seçme ve hali hazırda sürdürülmekte olan uygulamaların geliştirilmesinde rehber olarak yararlanılması önerilebilir.

\section{KAYNAKLAR}

Akerjordet, K., Severinsson, E. (2007). Emotional intelligence: A review of the literature with specific focus on empirical and epistemological perspectives Journalof Clinical Nursing, 16(8): 14051416.

Akıncı, A. Ç., Akgün, G. (2011). Kırklareli Üniversitesi Sağlık Yüksekokulu hemşirelik öğrencilerinin empatik eğilim ve becerileri. F.Ü. Sağllk Bilimleri Dergisi, 6(17): 53-65.

Akkoç, Z. (2007). Duygusal zekâ. Yayınlanmamış Yüksek Lisans Tezi, Kahramanmaraş Sütçü İmam Üniversitesi Sosyal Bilimleri Enstitüsü, Kahramanmaraş.

Arifoğlu, B., Razı, G. S. (2011). Birinci sınıf hemşirelik öğrencilerinin empati ve iletişim becerileriyle iletişim yönetimi dersi akademik başarı puanı arasındaki ilişki. Dokuz Eylül Üniversitesi Hemşirelik Yüksekokulu Elektronik Dergisi, 4(1): 7-11.

Augusto Landa, J. M., Lopez-Zafra, E., Berrios Martos, M. P., Aguilar-Luzon Mdel, C. (2008). The relationship between emotional intelligence, occupational stres and health in nurses: A questionnaire survey. International Journal of Nursing Studies, 45(6): 888-901.

Avşar, G., Kaşıkçı, M. (2010). Hemşirelik yüksekokulu öğrencilerinde duygusal zekâ düzeyi. Anadolu Hemşirelik ve Sağlık Bilimleri Dergisi, 13(1): 1-6.

Cevahir, R. ve ark. (2007). Hemşirelik öğrencilerinin devam ettikleri sinıflara göre empatik becerilerinin değerlendirilmesi. 6.Ulusal Hemşirelik Öğrencileri “Uluslararası Katılımlı” Kongresi Kitabı, İstanbul Üniversitesi Basım ve Yayınevi, İstanbul.
Dökmen, Ü. (1988). Empatinin yeni bir modele dayanılarak ölçülmesi ve psikodrama ile geliştirilmesi. A.Ü. Ĕgitim Bilimleri Dergisi, 21(1-2): 155-190.

Ergin, F. (2000). Üniversite öğrencilerinin sahip oldukları duygusal zekâ düzeyi ile 16PF kişilik özelliği arasındaki ilişki üzerine bir araştırma. Yayınlanmamış Yüksek Lisans Tezi, Konya Selçuk Üniversitesi Sosyal Bilimler Enstitüsü, Konya.

Freshwater, D., Stickley, T. (2003). The heart of the art: Emotional intelligence in nurseeducation. Nursing Inquiry, 11(2): 91-98.

Goleman, D. (2007). Duygusal Zekâ Neden IQ'dan Daha Önemlidir? Çeviren: B. S. Yüksel, 31.basım, Varlık Yayınları, İstanbul.

Ioannidou, F., Konstantikaki, V. (2008). Empathy and emotional intelligence: What is it really about? International Journal of CaringSciences, 1(3): 118-123.

Karabulutlu, E. Y., Yılmaz, S., Yurttaş, A. (2011). Öğrencilerin duygusal zekâ düzeyleri ile problem çözme becerileri arasındaki ilişki. Psikiyatri Hemşireliği Dergisi, 2(2): 75-79.

Karakaş, A. S., Küçükoğlu, S. (2011). Bir eğitim hastanesinde ça1ş̧an hemşirelerin duygusal zekâ düzeyleri. Anadolu Hemşirelik ve Sağlık Bilimleri Dergisi,14(3): 8-13.

Karakaya, A. D. (2001). Akdeniz Üniversitesi’ndeki hemşirelik öğrencilerinin empati becerileri. Yayınlanmamış Yüksek Lisans Tezi, İstanbul Üniversitesi Sağlık Bilimleri Enstitüsü, İstanbul.

Kaya, H., Keçeci, A. (2004). Bir hemşirelik yüksekokulu öğrencilerinin duygusal zekâ düzeyleri. İ.Ü. FlorenceNightingale Hemşirelik Dergisi, 13(52): 39-47.

Kuzu, A., Eker, F. (2010). Hemşirelik öğrencilerinin duygusal zekâ ve iletişim becerilerinin diğer üniversite öğrencileri ile karşılaştırmalı olarak değerlendirilmesi. Hemşirelikte Araştırma Geliştirme Dergisi, 3: 14-29.

McQueen, A. C. H. (2003). Emotional intelligence in nursing work. Journal of Advanced Nursing, 47(1): 101-108.

Mercer, S. W., Reynolds, W. J. (2002). Empathy and quality of care. British Journal of General Practice, 52: 9-13.

Mete, S., Gerçek, E. (2005). PDÖ yöntemiyle eğitim gören hemşirelik öğrencilerinin empatik eğilim ve becerilerinin incelenmesi. C. ̈̈. Hemşirelik Yüksekokulu Dergisi, 9(2): 11-17.

Nazik, E., Arslan, S. (2011). Hemşirelik öğrencilerinin empatik becerileri ile öz duyarlıkları arasındaki ilişkinin incelenmesi. Anadolu Hemşirelik ve Sağllk Bilimleri Dergisi, 14(4): 69-75.

Nunes, P., Williams, S., Sa, B., Stevenson, K. (2011). A study of empathy decline in students from five health disciplines during their first year of training. International Journal of MedicalEducation, 2: 12-17. 
Onay, M., Uğur, B. (2011). Sağlıktaki memnuniyetin sessiz sihri: Duygusal zekâ. Organizasyon ve Yönetim Bilimleri Dergisi, 3(2): 23-34.

Özcan, H. (2012). Hemşirelerin empatik eğilim ve empatik becerileri: Gümüşhane örneği. Gümüşhane Üniversitesi Sağllk Bilimleri Dergisi, 1(2): 60-68.

Özcan, C. T., Oflaz, F., Çiçek, H. (2008). Mesleki eğitimin hemşirelik öğrencilerinin empati beceri geliştirme düzeyi üzerine etkisi: Uzunlamasına çalışma. 6.Ulusal Hemşirelik Eğitimi "Uluslararası Katılımlı” Kongresi Kitabl, İstanbul Üniversitesi Basım ve Yayınevi, İstanbul.

Sevindik, F., Uncu, F., Dağ, D. G. (2012). Sağlık yüksekokulu öğrencilerinin duygusal zekâ düzeylerinin bazı değişkenler açısından incelenmesi. F.Ü. Sağllk Bilimleri Tıp Dergisi, 26(1): 21- 26.

Stein, S. J., Book, H. E. (2003). Duygusal Zekâ ve Başarının Sırrı. Çeviren: M. Işıı, Özgür Yayınları, İstanbul.

Tutuk, A., Al, D., Doğan, S. (2002). Hemşirelik öğrencilerinin iletişim becerisi ve empati düzeylerinin belirlenmesi. C.Ü. Hemşirelik Yüksekokulu Dergisi, 6(2): 36-41.

Uygun, E. (2006). Psikiyatri servisinde çalışan hemşirelerin empati beceri düzeylerinin belirlenmesi. Yayınlanmamış Yüksek Lisans Tezi, İstanbul Üniversitesi Sağlık Bilimleri Enstitüsü, İstanbul.
Ünsar, S., Fındık, Ü. Y., Sadırlı Kurt S., Ünsar, S. (2008). Edirne Sağlık Yüksekokulu öğrencilerinin duygusal zekâ düzeyleri. Bilim, Eğitim ve Düşünce Dergisi, 9(1): 1-15.

Yılmaz, S. (2007). Duygusal zekâ ve akademik başarı arasındaki ilişki. Yayınlanmamış Yüksek Lisans Tezi, Atatürk Üniversitesi Sosyal Bilimler Enstitüsü, Erzurum.

Yılmaz, E., Özkan, S. (2011). Hemşirelik öğrencilerinin duygusal zekâ düzeylerinin bazı değişkenler açısından incelenmesi. Maltepe Üniversitesi Hemşirelik Bilim ve Sanatı Dergisi, 4(1): 39-52.

Yurttaş, A. (2001). Sağlık yüksekokulu öğrencilerinin empatik becerileri ile problem çözme becerilerinin karşılaştırılması. Yayınlanmamış Yüksek Lisans Tezi, Atatürk Üniversitesi Sağlık Bilimleri Enstitüsü, Erzurum.

Ward, J., Cody, J., Schaal, M., Hojat, M. (2012). The empathy enigma: An empiricalstudy of decline in empathy among under graduate nursing students. Journal of Professional Nursing, 28(1): 34-40.

Zeidner, M., Matthews, G., Roberts, R. D. (2004). Emotional intelligence in theworkplace: A critical review. Applied Psychology, 53(3): 371-399. 